○特集 $\mid$ 人工膜関連シンポジウム「膜による水処理技術を展望する」

\title{
逆浸透膜を用いた水処理プロセスについて
}

\author{
川勝孝博 \\ 栗田工業株式会社 \\ × 329-0105 栃木県下都賀郡野木町川田五丁山 1-1
}

\section{Water Treatment Processes with Reverse Osmosis Membrane}

\section{Takahiro Kawakatsu}

Kurita Water Industries Ltd.

1-1, Gochoyama, Kawada, Nogi-machi, Shimotsugagun, Tochigi 329-0105, Japan

The reverse osmosis (RO) membrane plays a significant role in pure water production, waste water reuse, and valuable material recycle systems. Among RO membrane technologies, methods to seek and reduce membrane fouling sources, $\mathrm{RO}$ rejection increasing treatment, and the phosphate acid recycle system are presented in this paper.

Engineering companies have to develop technologies to obtain and maintain higher RO performance, also those to contribute resource saving and valuable material recycle.

Key words : Reverse osmosis membrane $/$ Membrane fouling / Rejection increasing treatment $/$ Valuable material recycle $/$ resource saving

\section{1. はじめに}

逆浸透膜装置は，純水製造，排水回収，あるいは 有価物回収といった水処理プロセスに㧍いて欠かす ことができない基幹ユニットであり，様々な周辺技 術, 商品が開発されている。ここでは, エンジニア リングメーカーとしての取り組みの事例として, 逆 浸透膜装置が使用される背景, 逆浸透膜污染対策と 逆浸透膜の阻止率向上, そして, 逆浸透膜を活用し た有価物回収について紹介する。

\section{2. 逆浸透膜装置}

栗田工業では, 用排水装置, 水処理薬品, メンテ ナンスの 3 つを事業の幹としており, 近年では, これ らの事業に扔ける技術エッセンスを集約した水供給 ビジネス（BOO, Build Own Operate）も伸びてきて

Tel: 0280-54-2616

E-mail: takahiro.kawakatsu@kurita.co.jp
いる. 超純水を製造し, 客先プロセスで生じた排水 を回収して再利用する, 超純水製造・排水回収シス テムの一例を Fig. 1に示す．様々なユニットが使用さ れているが, 一次純水システムに打ける逆浸透膜装 置の性能を高く維持することが課題であり, 特に, 逆浸透膜の透過流束を低下させる逆浸透膜污染に対 しては, 様々な対策を講じている. また, 後段のユ ニットの負荷の低減, あるいは, 阻止率が低下した 逆浸透膜を回復させることを目的として, 逆浸透膜 の阻止率を向上させる技術も開発している.

\section{3. 逆浸透膜污染対策}

\section{1 逆浸透膜污染の原因}

簡便なシステムでも膜污染を全く起こさずに 10 年 以上も稼働している逆浸透膜装置も存在するが, 何 も行わなくても安定運転できる逆浸透膜装置はほと んどないと言える. 逆浸透膜污染の原因として, ス ケールの生成, 付着による無機污染, 微生物の増殖 や付着による微生物污染, 微生物が生産した代謝物 


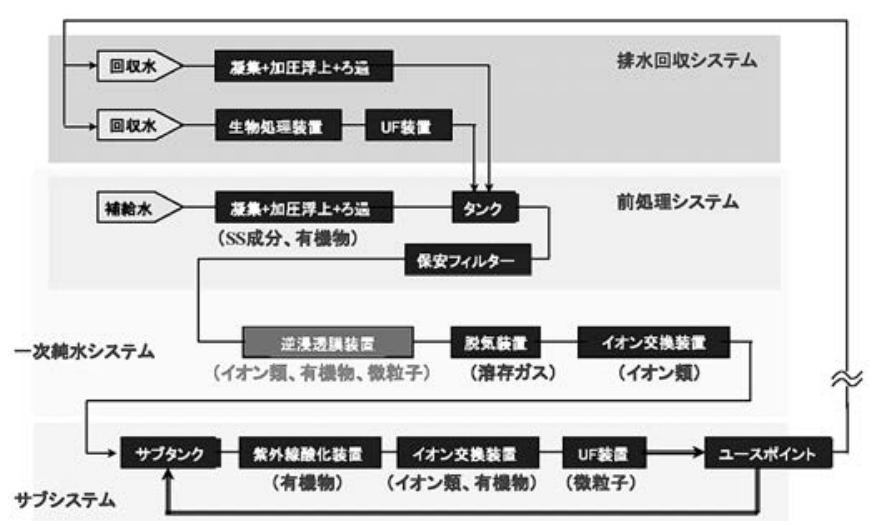

Fig. 1 Ultra pure water production and water reclamation system.

や人工の有機物による有機物污染が考えられる ${ }^{1}$.

現在の主流である芳香族ポリアミド逆浸透膜の表 面はヒダ状になっているが，この凹凸を 3D レーザー 顕微鏡で観察することができる．そして，膜污染に より透過流束が低下した膜の凹凸を 3D レーザー顕微 鏡で観察し，オリジナルの膜の凹凸に対する比を取 ることで, 膜污染によって凹凸がどのように変化す るかを調べることができる. Fig. 2 は污染膜の凹凸の 変化を横軸, 膜面の金属付着量を縦軸に取って, プ ロットしたものである。この方法によると，膜污染 のパターンは, 表面積比, 無機物量が共に増加して いる Type 1, 表面積比, 無機物量, 共に変化のない Type 2, 表面積比が減少し, 無機物量が増加してい る Type 3 に分けることができる. Type 1ではスケー ル粒子付着によるスケール污染, Type 2 では有機物 が単層に近い状態で吸着した有機物污染, Type 3 で は有機物と無機物が複合し，多層化することによっ て, 膜の凹凸が減少した有機・無機複合污染が考え られる2).

有機・無機複合污染を引き起こす有機物の解析を 行っている．有機・無機複合污染している逆浸透膜 装置の濃縮水と, 逆浸透膜の洗浄水を採取し, 生物 代謝物である中性糖, 酸性多糖, アミノ糖, タンパ ク質を分析した。なお，分析手法は，中性糖はアン トロン・硫酸法（標準物質：デキストラン), 酸性多 糖はカルバゾール・硫酸法（標準物質：D - デルク ロン), アミノ糖はエルソンモルガン法（標準物質： $\mathrm{N}$-アセチルグルコサミン)，タンパク質は Lowry-Follin 法（標準物質：人血清アルブミン）で ある. また, 分析に際し, 濃縮水はさらに濃縮, 脱 塩, 洗浄水も脱塩処理を施している. 分析結果を Table 1 に示す．洗浄水中には，濃縮水中には検出さ れない酸性多糖やタンパク質が見られ，アミノ糖の 比率も大きくなっている.この結果から, 酸性糖,

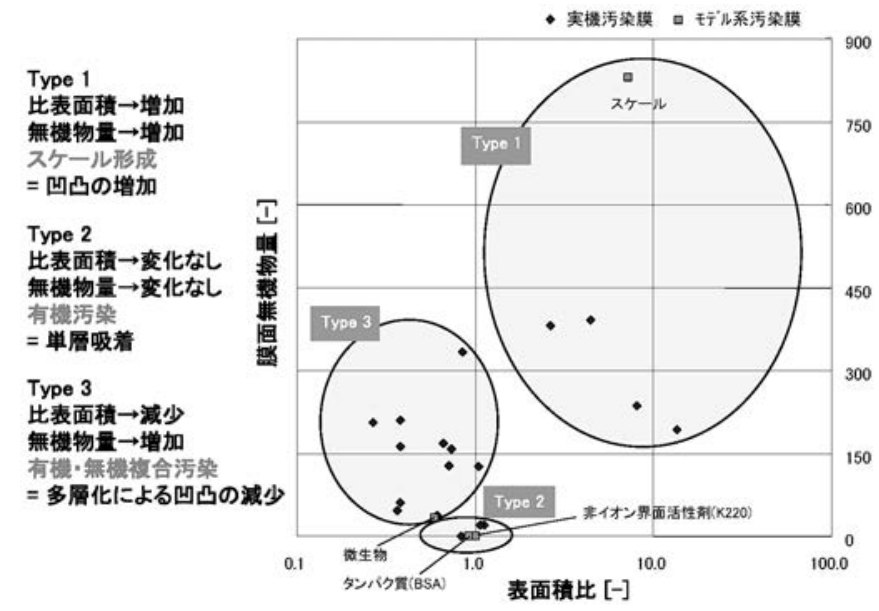

Fig. 2 Fouling type analysis of reverse osmosis membrane.

Table 1 Organic material constituents in reverse osmosis concentrate and washing solution after reverse osmosis membrane washing

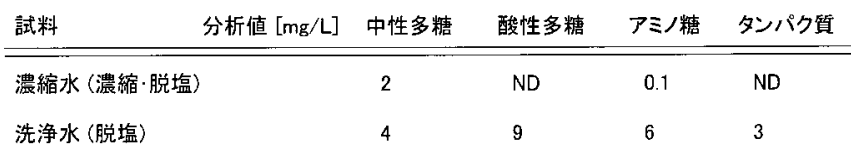

アミノ糖, タンパク質の荷電に対して金属がバイン ダーとなることで, 吸着層が多層化し, 膜の凹部が 閉塞, 凹凸が減少する機構を推定することができる. 以降に, Type 1におけるスケール污染対策, Type 2 における有機物污染対策, Type 3 における有機・無 機複合污染対策について述べる.

\section{2 スケール污染対策 11}

炭酸カルシウム, シリカ等, また, 主として凝集 剂由来の鉄, アルミニウムは, 膜表面に付着して透 過流束を低下させる。これらのスケールの生成, 付 着を抑制する手段として, 濃縮倍率, 温度, $\mathrm{pH}$ な゙ の運転条件の最適化, 脱炭酸, 軟化装置の設置など を挙げることができるが，スケール分散剤の使用も 有効である. 分散剂には, EDTAやEGTA等のキレ 一ト系, ヘキサメタリン酸等のリン酸系, 共重合ポ リマー等の高分子系がある. キレート系は, 多価力 チオンに対して強力な捕捉効果があるが, 当量レべ ルの添加量が必要である. リン酸系は, 低濃度で効 果を発揮するが, 分解し易く微生物のリン源となる リスクがある. 高分子系は, 低濃度で効果を発揮し, 水溶液状態で安定であり, カルシウム, シリカ, 鉄, アルミニウムなど, 対象のスケールによって構造, 配合を選択することができる.

シリカスケール分散剤を例に挙げる．Mアルカリ 度 $70 \mathrm{mg} / \mathrm{L}$, シリカ $50 \mathrm{mg} / \mathrm{L}$, 塩化ナトリウム 500 


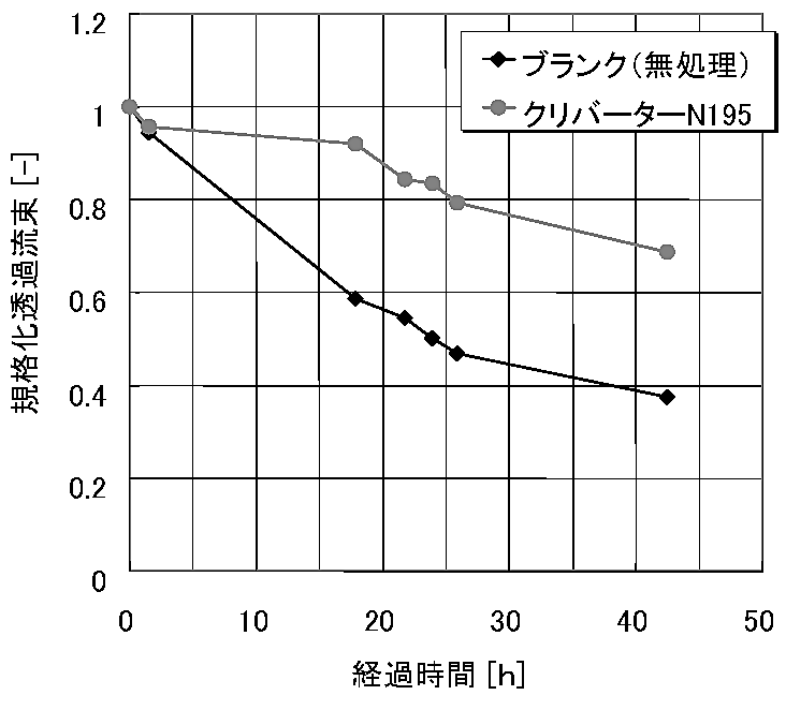

Fig. 3 Normalized fluxes in blank (non-treated) water and treated water with antiscalant (N195).

$\mathrm{mg} / \mathrm{L}$ ，アルミニウム $0.2 \mathrm{mg} / \mathrm{L}, \mathrm{pH} 8.0$ の模擬供給水 を調整し，微生物抑制剂として，クリバーター ${ }^{\circledR} \mathrm{EC} 503$ を $3 \mathrm{mg} / \mathrm{L}$ 添加した（EC503については後 述).そして, 分散剤処理をしないブランクと, 分散 剤としてクリバーター ${ }^{\circledR} \mathrm{N} 195$ を $20 \mathrm{mg} / \mathrm{L}$ 添加した場 合の超低圧逆浸透膜（日東電工社製 ES20）の透過流 束の変化を調べた。実験条件は, 流通式平膜セル （有効膜面積： $8 \mathrm{~cm}^{2}$ ) を用いたクロスフロー濾過方 式, 操作圧力（ポンプ加圧） $0.7 \sim 1.0 \mathrm{MPa}$, 原液流 量 $1 \mathrm{~mL} / \mathrm{min}$, 回収率 $80 \%$ （5倍濃縮 $=250 \mathrm{mg} / \mathrm{L}$ as シ リカ）である．結果を Fig. 3 に示す．分散剂を使用す ることで透過流束の低下を抑制できていることが分 かる. Fig. 4 は, 試験後の膜表面を電子顕微鏡で観察 した結果であるが，分散浏を使用することで，シリ カスケールの析出が大きく抑制されていることが分 かる. ブランク膜のようにスケールが付着すると, 3.1節で記述したType 1における膜の凹凸と無機物量 の増加を引き起こす。

\section{3 有機物污染対策}

有機污染を防止するためには，前処理システムや 排水回収システムにおける凝集条件を最適化し，有 機污染物質を可能な限り除去する必要がある．滞留 時間, 擋拌速度, $\mathrm{pH}$ の調整はもとより, 有機物量に 応じた凝集剤の量の最適化も重要である，凝集剂は 少ないと有機污染物質を残存させ，多すぎると余剩 の凝集剂が逆浸透膜を污染させる．このため，供給 水中の有機物量, 濁度, 処理水の性状に基づき, 凝 集剤の添加量を制御するシステムを開発している ${ }^{3}$. また, 凝集フロックを大きくし, 安定化させ, 分離

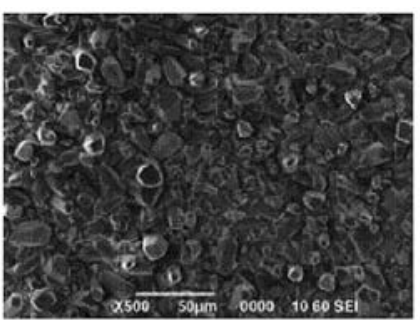

ブランク

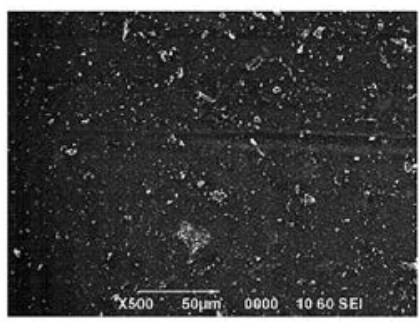

クリパーターN195使用
Fig. 4 SEM photomicrographs of blank membrane surface and antiscalant (N195) treated membrane surface.
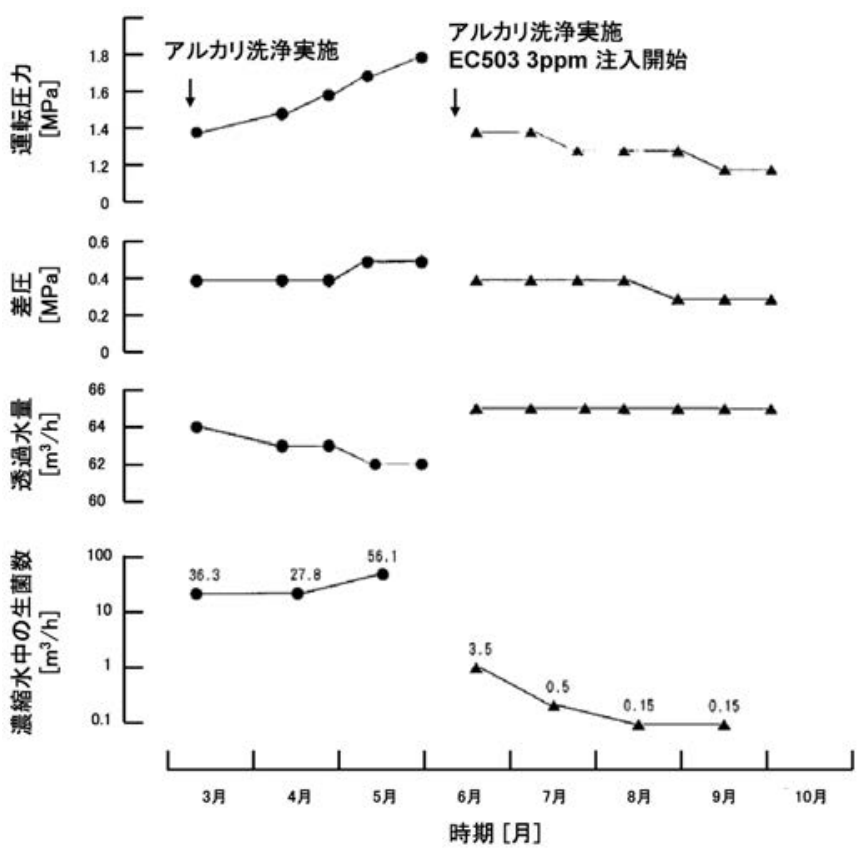

Fig. 5 Effect of slime control agent (EC503).

を容易にし，凝集剤の総量を低減（污泥を低減）す るクリバーター ${ }^{\circledR} \mathrm{EP}$, 鉄やアルミニウム系の凝集 剂では除去が困難な荷電性の低い有機物を除去する クリバーター ${ }^{\circledR B P}$ が凝集助剤として開発されている.

\section{4 有機・無機複合污染対策}

3.3 節で述べた凝集条件の最適化と共に, システム 内での微生物の発生と代謝物の生産を抑制する必要 がある。そのためにスライムコントロール剂を使用 する. クリバーター ${ }^{\circledR E C} 503$ は, 環状の窒素・硫黄系 化合物であり, Fig. 5 に示すように, 使用することで, 運転圧力, 差圧 (モジュール入口と出口の圧力差) を低下, 透過水量を安定化, 濃縮水中の生菌数を減 少させることができている.

クリバーター ${ }^{\circledR} \mathrm{IK} 110$ は, 新しいタイプの結合塩素 系化合物である.1種類のスライムコントロール剤を 使用していると耐性菌が現れることが多いが, EC503 と交互に使用するなど, 併用することで微生 


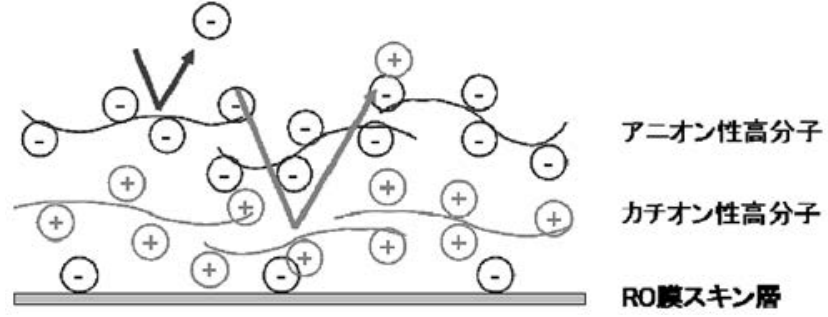

Fig. 6 Mechanism of ion rejection with a reverse osmosis membrane coated with cationic polymer and anionic polymer.

物抑制効果をさらに高めることができる。また，膜 面に付着した有機污染物質を剥離する効果も認めら れている4).

\section{5 污染膜の洗浄}

污染原因によって洗浄方法を選定する．無機物に 対しては酸，有機物に対してはアルカリが有効であ り, 污染Typeに応じてこれらを組合せて使用する5 ${ }^{5}$.

\section{4. 逆浸透膜の阻止率向上 ${ }^{6)}$}

河川水中に含まれるシリカ濃度は, 全国平均は 20 $\mathrm{mg} / \mathrm{L}$ 程度で, 北海道, 九州では $30 \mathrm{mg} / \mathrm{L}$ に達する. 本土では $20 \mathrm{mg} / \mathrm{L}$ を切る地域が多いが，井水の場合 は $20 \sim 70 \mathrm{mg} / \mathrm{L}$ と高い場合がある．供給水中のシリ 力濃度が高いと回収率（濃縮倍率）を上げられない だけでなく, 透過水中の濃度が上昇し, 後段のユニ ットの効率低下や水質悪化をもたらす。ここでは, 低濃度の荷電性高分子溶液を通水して, ポリイオン コンプレックス高分子層を形成させて電解質, 弱電 解質の阻止率を向上させる技術を紹介する. Fig. 6 に 逆浸透膜面にポリイオンコンプレックス層を形成さ せて，イオンの阻止率を向上させる機構の模式図を 示す．カチオン性高分子の薄層の上にアニオン性高 分子の薄層を形成させることでアニオンとカチオン の阻止率を向上させることができる．弱電解質であ るシリカに対しても, オリジナルの逆浸透膜のシリ 力除去率が $99.4 \%$ でれば，透過水中の濃度が $1 / 2$ と なる $99.7 \%$ にすることができる. Fig. 7 に 45〜 50 $\mathrm{mg} / \mathrm{L}$ のシリカ水溶液の長期通水試験を行った結果を 示す．使用膜は日東電工社製 ES20（8インチエレメ ント) である.6ケ月に渡って安定した性能が得られ ている.

\section{5. 有価物回収}

リン酸含有排水に対して, 従来は消石灰でリン酸

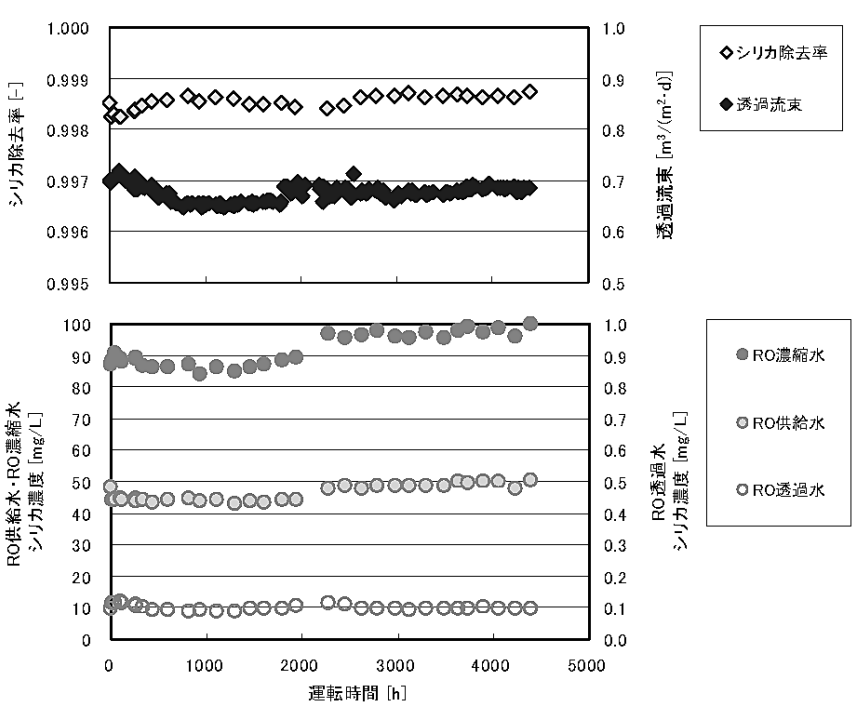

（摷作圧力 $0.74 \sim 0.76 \mathrm{MPa}$ ，回収率 $0.517 \sim 0.577$ ，水温 $24.7 \sim 28.4{ }^{\circ} \mathrm{C}$ )

Fig. 7 Time course of flux, silica rejection, feed silica concentration and permeate silica concentration with the rejection enhanced reverse osmosis membrane.

カルシウムを析出させ, 污泥としてリン酸除去を行 っていた. リン酸カルシウムの污泥をリン酸資源と するためには, 脱水, 乾燥工程が必要であり, 高コ ストなことからほとんどが産業廃棄物となっていた。

2 種の同符号のイオンが存在し，一方のイオンの膜 透過性が悪い場合, 電気的中性条件を満たすために, 他方のイオンが透過側に濃縮される現象が知られて いる ${ }^{7,8)}$. 栗田工業は, この原理を工業的に応用した 逆浸透膜リン酸回収システムを実用化している ${ }^{9,10)}$. このシステムによって，例えば，リン酸濃度 3000 $\mathrm{mg} / \mathrm{L}$ の排水 $100 \mathrm{~m}^{3}$ に対して, 従来法では, $855 \mathrm{~kg}$ （含水率 $40 \%$ ）のリン酸カルシウム $\left(\mathrm{CaHPO}_{4}\right)$ 污泥 が生成していたが，有価物として使用可能な $50 \%$ リ ン酸水溶液 $0.54 \mathrm{~m}^{3}$ を得ることができる.

Fig. 8にリン酸回収システムフローを示す。排水中 に存在しているリン酸, 酢酸, 硝酸から, リン酸の みを阻止し, 䣷酸, 硝酸が透過する逆浸透条件で, リン酸を $8 \%$ まで濃縮した後, 減圧蒸発濃縮を行うこ とで, リン酸濃度 $50 \%$ を実現している. 本システム では逆浸透膜によるリン酸の濃縮と酢酸, 硝酸の除 去が重要となる. Fig. 9 に逆浸透膜とエバポレーター におけるリン酸, 䣷酸, 硝酸の濃度を示す. リン酸 は逆浸透膜で濃縮されているのに対して, 酢酸, 特 に硝酸は減少している。 これは, 酢酸, 硝酸は透過 側に濃縮されているためである. Fig. 10 にリン酸濃 度と各酸（リン酸, 硝酸, 酢酸) の阻止率の関係を

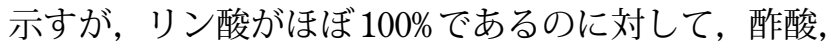
特に硝酸は負の阻止率を示すことが分かる. Fig. 11 で示すように，大分子量であるリン酸が阻止され， 


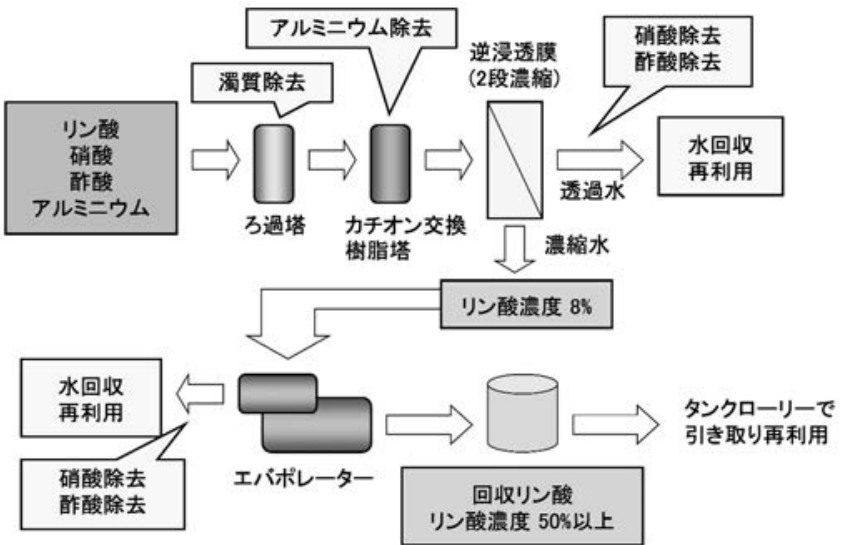

Fig. 8 Phosphoric acid recycle system flow.

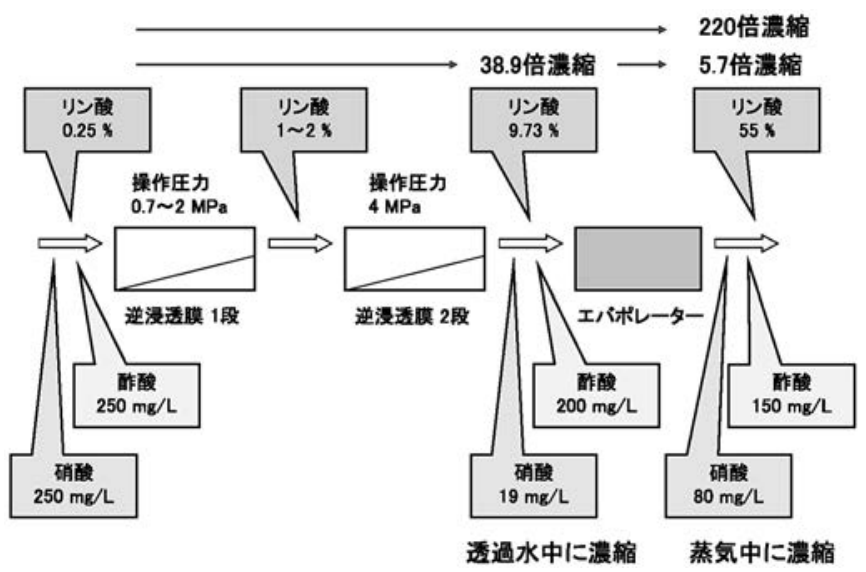

Fig. 9 Concentrations of phosphoric acid, acetic acid and nitric acid in reverse osmosis and evaporator.

最も低分子量の水素イオンが透過することで, 電気 的中性条件により，対イオンとして硝酸イオンや酢 酸イオンが透過していると考えられる.

\section{6. 終わりに}

芳香族ポリアミド逆浸透膜が出現し，その低圧化， 超低圧化，量産化やエネルギー回収技術の開発など の低コスト化が行われた結果，海水淡水化，純水製 造，排水回収などにおいて，逆浸透膜システムの採 用は，これから益々伸びていくと予測される。 今後 も，エンジニアリングメーカーとして，逆浸透膜を 安定に使うための技術，より高い性能を得るための 技術，省資源，有価物回収に役立てられる技術を開 発して行きたいと考えている。

\section{文献}

1）川勝孝博 : ファウリングにおける実用例と対策,「膜の 劣化とファウリング対策」(NTS), 129-143 (2008)

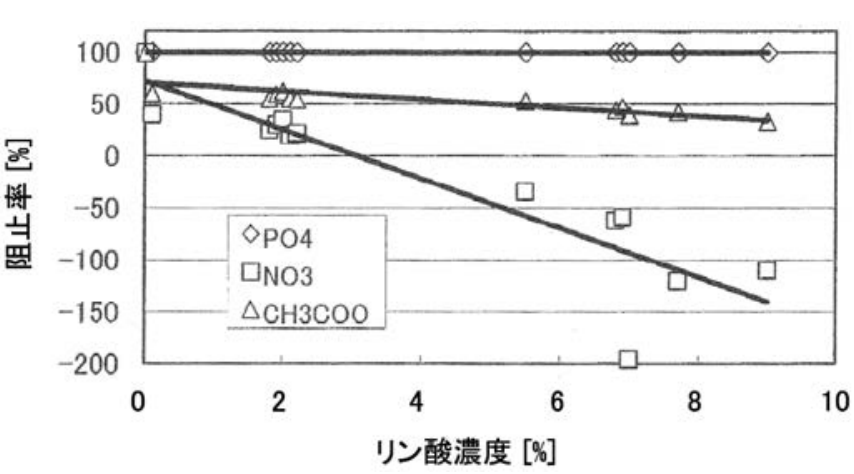

Fig. 10 Relationship between concentration of phosphoric acid and acid rejections for phosphoric acid, acetic acid and nitric acid in reverse osmosis membrane separation.

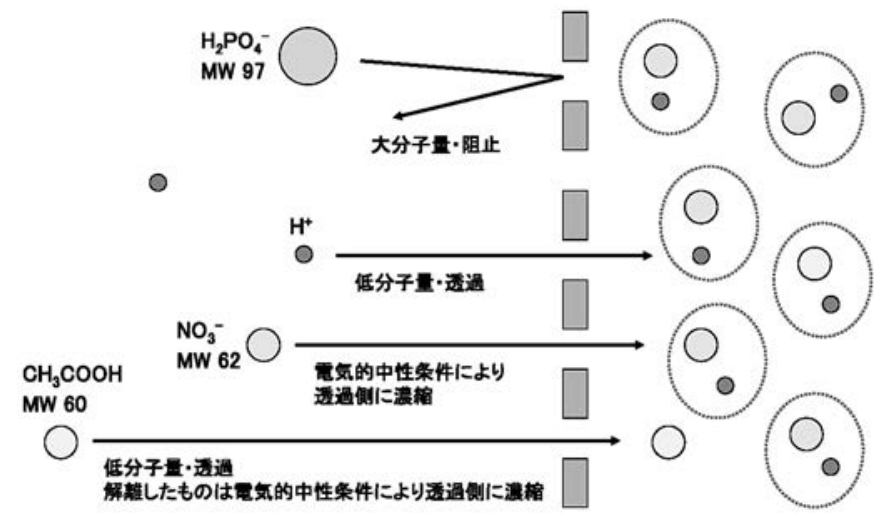

Fig. 11 Schematic transport mechanism of phosphoric acid, acetic acid, nitric acid and proton in reverse osmosis membrane separation.

2) 伊澤周平, 川勝孝博 : 膜分離装置の污染状態の診断方法, 診断装置, および膜分離装置の洗浄方法, 特開, 200714878

3）多田景二郎, 澤田繁樹 : 溶解性有機物を指標とした凝集 剂添加濃度制御, 第 15 回衛生工学シンポジウム (2007)

4) 育野 望: メンブレンシステムにおける水回収事業, 二 ューメンブレンテクノロジーシンポジウム, S8-2-1 - S8$2-13(2008)$

5) 川勝孝博 : 膜洗浄の実際,「膜の劣化とファウリング対 策」(NTS), 191-200 (2008)

6) 川勝孝博, 織田信博, 早川邦洋 : 透過膜の阻止率向上剂, 阻止率向上方法, 透過膜及び水処理方法, 特開, 2006110520

7) Tsuru T, Nakao S, Kimura S : Calculation of ion rejection by extended Nernst-Plank equation with charged reverse osmosis membranes for single and mixed electrolyte solutions, J. Chem. Engineering fo Japan, 24(4), 511-517 (1991)

8) Tsuru T, Urairi M, Nakao S, Kimura S : Reverse Osmosis of single and mixed electrolytes with charged membranes: Experiment and analysis, J. Chem. Engineering fo 


\section{Japan, 24(4), 518-524 (1991)}

9) 三輪昌之: 電子産業排水からのリン酸回収, EICA, 14(1), 27-30 (2009)

10) 織田信博: 工場排水および未利用資源からのリン回収, 「リン資源の回収と有効利用」(サイエンス＆テクノロ ジー), pp.214-223 (2009)

(Received 24 May 2010;

Accepted 3 June 2010)

\section{著者略歴}

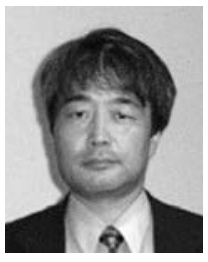

川勝 孝博（かわかつ たかひろ）

昭和 62 年 3 月 東京大学教養学部基 礎科学第一学科卒業

平成元年 3 月 東京大学大学院工学 系研究科化学エネル ギー工学専攻修士課 程修了

平成 5 年 4 月 農林水産省食品総合 研究所食品工学部 プロセス工学研究室 科学技術庁 科学技 術特別研究員

平成 5 年 11 月 東京大学大学院工学 系研究科学位博士 (工学)取得

平成 8 年 3 月 東北大学大学院工学 研究科化学工学専攻 プロセス要素工学講 座反応プロセス工学 研究室 助手

平成 11 年 5 月 スウェーデン・ルン ド大学食品工学科 博士研究員

平成 12 年 12 月 東京大学大学院工 学系研究科化学シス テム工学専攻科学技 術振興事業団 博士 研究員

平成 14 年 6 月 栗田工業入社（至現 在) 